\title{
Worship and the Lord's Supper in Assemblies of God, and other selected Pentecostal churches in Nigeria
}

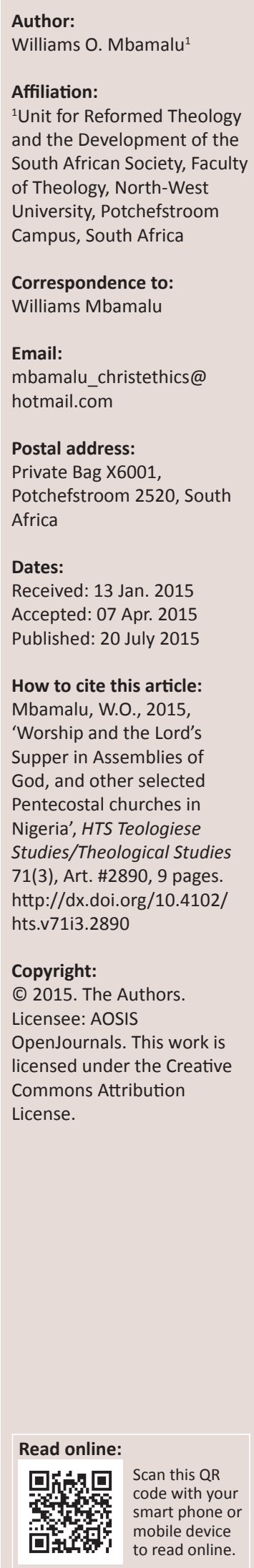

Pentecostals' dominant liturgical principle has traditionally taken the pattern of unlimited expression of emotion and charismata, often formless and emphasising the subjective. The manifestations of the Spirit's direct activity often interpreted as the reason for Pentecostals' antiliturgical position, have in the past few years passed through a paradigm shift. The introduction of concrete rituals encompassing various significations, in a manner reminiscent of African traditions and culture by some churches, shows uncritical engagement with biblical theology of worship. Furthermore, the encouragement of individual appropriation of God's promise in rites performance is a deviation from African traditional emphasis on community function. The researcher employed a participant observation methodology and engagement with pertinent literary works of pastors of the churches investigated. The article shows that the struggle of Pentecostals to be relevant is responsible for its juxtaposition of African traditions and culture with the Spirit in the performance of liturgical rites. The article concludes that in Nigeria Pentecostals' practice of worship encourages the individual to appropriate the biblical promises of God at the expense of the community of Christ whose work in building character and guiding our lives is done through other Christians in the community.

\section{Introduction and brief historical overview of Pentecostals in Nigeria}

The purpose of this article is to interpret how liturgy functions in Assemblies of God, and other selected Pentecostal churches in Nigeria, such as the Living Faith Tabernacle (always known as Winners Chapel), and the Redeemed Christian Church of God (RCCG). Three strands of Pentecostal liturgy in Nigeria emanated from the mainstream churches, the African Initiated churches (AIC), and from African tradition and culture. Religiously speaking, Nigeria is truly the giant of Africa with a worshipping population of over 150 million. Nigeria is twice the size of Egypt, three times the size of South Africa, and 12 times the size of Zambia. The country has over 200 ethnic groups and over 400 languages. The 'Big Three' major ethnic groups are the Yoruba in the southwest, the Ibos in the southeast and the Hausa-Fulani in the north. The minority ethnic groups together, however, are more or less equal in number to the 'Big Three' combined (De St. Jorre 1972). According to Cole (2007):

Nigeria is said to have the world's third largest population of Pentecostals with 3.9 million members, following Brazil with 24 million and the United States with about 6 million adherents.

Nigeria has the largest number of Pentecostal Christians in Africa with Assemblies of God, Nigeria (founded in 1939) acclaimed as the mother of Pentecostals in Nigeria. The Assemblies of God, Nigeria (henceforth AGN) started life as an indigenous African Pentecostalism by Africans of the Igbo ethnic group. The group no sooner than it started ceded its indigenous existence and autonomy to the American Mission of the Assemblies of God in West Africa (McGee 1986:146). According to Kalu (2008:41) it is indubitable that 'African Pentecostalism has African roots, the implication is that early classical Pentecostal' missionaries many a time came into Africa at the behest of indigenous Christians.

The AGN started between 1931 and 1935 when two groups of 'Holy Ghost seekers' at Odebe in Old Umuahia ${ }^{1}$ and Ikot Ekpene, ${ }^{2}$ and Port Harcourt in the south-eastern part of Nigeria sought and received the baptism in the Holy Spirit with evidence of speaking in tongues as it happened in Acts 2:4. From thence this African initiated Pentecostal movement went on by the name 'Church of Jesus Christ' (CJC) and began to establish churches all over the place. The repentance and the faithful obedience of these African men and women at Old Umuahia, Ikot

\footnotetext{
1.This group had established 10 churches in Umuahia, Enugu, Ishan, and Igede areas before handing them over to the American Assemblies of God Mission.
} 
Ekpene and Port Harcourt are the basis for a preparatory formation of its embryonic narrative theology, for as Dyrness (1989) puts it:

Theology is reflection upon the movement of mission that is already in process when a person or group responds to Jesus Christ. The shape of this response will reflect the particularities of the setting and the subsequent reading of Scripture will reflect back critically on that setting. (p. 7)

Theology is the story-telling about what God has done for humankind, and this embodies liturgy by a particular community of people within their cultural setting. Every story-telling about God is usually done in the light of people's particular cultural and historical reading of Scripture (Dyrness 1989:7). The particular theology and culture of these native African Pentecostals who were soundly converted and who had experienced the baptism of the Holy Spirit in their village, Old Umuahia, was soon botched. The Old Umuahia theological narrative was eclipsed by a bigger story of the 'Azusa Street Revival' in USA (McGee 1986:43-44), where the Assemblies of God were formed in 1914. American Assemblies of God started when mainstream churches separated themselves from the revival movement whose members spoke in tongues and made claims of divine healing. From that singular incident, printed literature from American Pentecostal groups, such as Faith Tabernacle in Philadelphia, the Assemblies of God, and Faith and Truth Temple of Toronto (Sanneh 1983: 184-185) were exported into Africa. Thus the story of conversion and the pneumatic experience of these indigenous Africans came in contact with the story of the phenomenon associated with the coming of the Holy Spirit during revivals at Azusa Street, where men and women were actually speaking in tongues as well as working miracles in the United States of America. This indigenous movement had established a number of churches and only had to prayerfully request the American Assemblies of God to send them a resident missionary. The story of the missionaries and the story of the indigenous movement group clashed and culminated in two extreme reactions, namely either to affiliate with Pentecostals from America, or orchestrate total disengagement from the influence of what was termed 'foreign religious organisation' (Sanneh 1983:185). The CJC formalised affiliation with Assemblies of God in August 1939 in Springfield Missouri, USA, and became officially renamed 'Assemblies of God' Nigeria (Assemblies of God 1994:6). The affiliation marked the first paradigm shift in AGN, and this resulted in CJC's loss of its true African identity, as it adopted America's theology, liturgy and culture. Bernard Lonergan's (1973:xi) remark remains valid that 'a theology mediates between a cultural matrix and the significance and role of a religion in that matrix'. An envisaged symbiotic relationship between the CJC and missionaries of the American Assemblies of God resulted in a total assimilation of the Old Umuahia narrative theology and culture. This manifest unequal relationship was conducive for the implementation of the North American Pentecostal pattern of organisation that displaced an indigenous church structure and liturgy expressible in African culture within the Nigerian context.

The American overseas mission organisation in Nigeria operated a paternalistic mission station approach which lasted for more than three decades. The affiliation of such a minority group as the CJC with a larger group, the American Assemblies of God, came with obligation on individuals within the minority group to subordinate themselves to the rules and culture of the larger group. A significant benefit of the American mission was the founding of Bible institutes for the training of indigenous leadership in the image of American culture. ${ }^{3}$ Without contextualising the materials used in teaching students, the training done in AGN Bible institutes did not include or emphasise the 'theological story' of the prospective local converts from Umuahia. It was in the Bible institutes, that AGN experienced total assimilation of its indigenous theologies and liturgy. This marked the beginning of the loss of the Umuahia pre-understanding in the interpretation of Scripture for theology and praxis within the framework of responsible existence in private and public spheres. The present Assemblies of God, and in relation to other Pentecostals in Nigeria, have gone through a paradigm shift that striped the Pentecostals of its foreign theologies and liturgies.

\section{Theoretical framework from church history}

In what manner did early Christians define the theology of their worship? Theology, like any other scientific endeavour, is not immune to a significant paradigm shift when new orientation is envisaged. Thomas Kuhn in his book, The structure of scientific revolutions, (1962) states that changes occur in science when there is a paradigm shift. What Kuhn means is that any current academic discourse is a constellation of ideas and concepts that contribute an interpretative scheme for the scientific community. The Christian community started its existence as an attaché sect, just like other sects within the framework of Judaism. Josephus (1981) uses the word dip $\varepsilon_{\sigma i \varsigma}$ [sect] to denote the parties within Judaism:

\footnotetext{
... there were three sects among the Jews, who had different opinions concerning human actions; the one was called the sect of the Pharisees, another the sect of the Sadducees, and the other the sect of the Essenes. (p. 274)
}

The fourth group, called the Zealots - though not encouraged by Christians - championed the cause of political alternatives and sabotaging the ruling powers (VanGemeren 1988:322). The existence of these four parties within the structure of the well-defined religious community, according to Bright (1959:466) 'are an index of the fact that Jews were not agreed regarding what Israel should be and what course her future

3.African attires that blend with the wearing of jewellery were considered sinful because the practice was associated with women of low moral standards. For men, professional attire is the standard and includes suits, dress shirts with or without ties, collarless knit shirts with a jacket, sweaters, polo or golf-style shirts, and shoes. Professional attire does not include tshirts, tight fitting pants of any kind and jean of any colour. A pastor could be disciplined for wearing a traditional attire to preach on Sunday service. Bible interpretation avoided using illustration from native stories and culture. 
ought to take'. Christianity, which happened to be the last sect from the loins of Judaism, proclaimed that 'the destination of Old Testament history and theology is Christ and his gospel' (Bright 1959:467). The disciples of Jesus Christ themselves called their congregation 'The Way' (Ac 9:2; 19:9, 23; 24:14, 22), and much later fellow-Jews ridiculed members of the sect by referring to them as Nazarenes (Ac 24:5; Mt 2:23).

The distinguishing feature that marked out the sect of 'the Way' - though the Jewish term for them remained 'Nazarenes' - was their adherence that the climatic revelation of God was fully manifest in Jesus of Nazareth. This Jesus had asked 'Who do people say the Son of Man is?' A question to which the response was, 'You are the Christ, the Son of the living God' (Mt 16:18). It is on this Christ (Messiah) that all people of God constitute members of one household, 'built on the foundation of the apostles and prophets, with Christ Jesus himself as the chief cornerstone' (Eph 2:20). The gospel rapidly reached Antioch of Syria where the pagans soon gave them the nickname 'Christians', which became a popular term (Ac 11:26). 'Because of this deep sense of continuity, various ideas and attitudes characteristic of traditional Judaism became and have largely remained integral to the structure of Christian thought' (Chadwick 1993:1) Paul thought of the church as a commonwealth of nations where the barrier between Jew and Gentile is broken down (Eph 2:14-22); and for sure Christians in Palestine long remained a group within Judaism. Issues of liturgy became problematic and in about 85 pronounced a formal anathema, which was incorporated in the synagogue liturgy: 'May the Nazarenes and the heretics be suddenly destroyed and removed from the Book of Life' (Chadwick 1993:1). Jewish Christians 'continued to use the temple as a place of worship and observed the Jewish law including its ceremonies, circumcision, and the dietary' (Latourette 1975:67). Jewish Christians' observance of Sabbaths, circumcision, and other Jewish feasts distressed many Gentile Christians who withdrew their support of the Jewish groups, and slowly the Jewish community lost importance (Chadwick 1993:22).

The above account of how the Early Church operated provides theological and liturgical paradigms and an interpretative scheme for Pentecostal's liturgical discourse. Early Christianity depended on a common faith and a common way of life and worship focused on the person and teaching of Jesus Christ. Naturally all patterns of worship the rite of baptism, and the Lord's Supper - derived all its meaning from its reference to Jesus Christ. Apart from other constituents of Christian liturgy that have undergone changes, the water baptism and the Lord's Supper remains dynamic and relevant in mainline and Pentecostal churches. In the history of Christianity, the development of liturgical hermeneutics has followed the path of historical paradigm shifts in core theories of Christology, soteriology and ecclesiology. However, 'Christianity entered into the inheritance of an already existing pattern of worship, provided by the Temple ritual and synagogue Liturgy' (Martin 1964:19). Few aspects of Christian theology have gone through the process of paradigm shifts like Christian worship and art. Christian art is a sacred art - traced from the end of the 2nd century and the beginning of the 3rd century that uses figurative representations, themes and imagery from Christianity. In terms of worship, Scripture records that it was customary for Christians to meet and celebrate the first day of the week as the day of the Lord's resurrection (Ac 20:7; 1 Cor 16:2). It was the resurrection faith that brought the scattered followers of Jesus together again as a dynamic and self-propagating community (Bruce 1969:206). In the Early Church community, public worship was paramount and Sunday service consisted of two parts: general congregation service and exclusive service called missus or missa [mass], mainly for communicants (Boer 1976:143).

The Early Church did not question the validity of baptism and the Lord's Supper as sacraments. However, by 1439 the number of sacraments had become seven, namely baptism, Eucharist, confirmation, ordination, penance, extreme auction, and matrimony (Latourette 1975:528). In the 16th century the Reformation rejected these, recognising only baptism and the Lord's Supper. The liturgy of Pentecostal churches finds its roots in the radical holiness movements of the 19th century Wesleyan doctrine of sanctification, and convictions regarding Jesus Christ as saviour, healer, baptiser with the Holy Spirit, and coming king (Work 2006:574). However, the Pentecostal movement cannot be understood apart from its strand from the original apostolic church as depicted in the book of Acts. It is the strongest persuasion of those who belong to this movement that the term 'Pentecostal revival' implies that the first Pentecost ought to be repeated in the life of any Christian which has had a genuine conversion experience (Bloch-Hoell 1964). Pentecostals appropriate the Holy Spirit's influence on the original apostles, and upon such experience erect their own distinctive liturgical forms and convictions in their ecclesiastical and instructional materials based on Acts 2:38, 8:17, 10:4-45, and 19:6.

In sum whenever a dominant theological or liturgical paradigm no longer serves as an effective framework for the interpretation of the concerns of a people's existential contexts, then a paradigm shift in liturgical hermeneutics becomes inevitable. Evidently, when a paradigm becomes irrelevant, its language also becomes obsolete within the changing context and since liturgy and theology are dynamic interactive processes within contexts, a revisitation of its articulation calls for a constant academic endeavour. The extent to which one may argue back or work to derive a theoretical framework from the fossils embedded in the later liturgies is difficult to establish. Thus the historical theoretical framework pursued to this point is justified.

\section{Liturgy and theological training: From missionary paradigm to African traditional paradigm}

The dominant paradigm of Missionary Bible institutes established in Nigeria did not prioritise on the training 
of theologians. The Pentecostals never developed any scholarly theology during the first 100 years of its existence in West Africa (Bloch-Hoell 1964:97). For example, from 1940 to 1980 all AGN Bible institutes operated a diploma level programme and mainly trained pastors for local ministry of the church. Such rudimentary training in these Missionary Bible institutes was narrow, repetitive and circumscribed within the study of biblical books in canonical order (Spittler 1983). Rarely do courses in these training institutes resound a critical investigation of theology, liturgy and hermeneutics cognisant of African culture and context. Although theology and liturgy have the potential of binding groups together, these are the very terms that expatriate Pentecostal missionaries deliberately rejected, to avoid any sacramental connection with the Roman Catholic Church. Linguistically, and from a socio-cultural perspective, it appears more fitting and acceptable for non-African missionaries to use 'ordinance and ceremony' as instruments for instruction in mission Bible institutes. Coincidentally, the term ceremony finds resonance in traditional Africa where it serves the importance of teaching and unifying the people. More importantly too is that African religious beliefs are concerned with God, spirits, human life, and the hereafter (Mbiti 1991:11), and perform ceremonies and festivals that embody praying, offerings, singing and dancing, eating and drinking, celebrating the birth of a child and harvest season (Mbiti 1991:11). Apart from Pentecostal's claim that original apostolic inspiration informed their worship, the hidden transcript is that African traditions also serve as an appreciable context in performing Pentecostal liturgy. This is much evident in their teachings on tithes and offerings, the Lord's Supper, the anointing oil and other paraphernalia of rites.

Reading through a book in which a fraction of a chapter is devoted to 'what we believe', the AGN lists the following 17 fundamental truths: The Scripture inspired; the one true God; the Deity of the Lord Jesus Christ; the fall of man/woman (sic); the salvation of man/woman (sic); the ordinances of the church; the baptism in the Holy Spirit; the initial physical evidence of the baptism in the Holy Spirit; sanctification; the church and its mission; the ministry; divine healing; the blessed hope; the millennial reign of Christ; the final judgement; and (the new heaven and the new earth. Marriage ordinance is not listed, and other ceremonies such as child dedication and house dedication are not listed in the official document called 'Assemblies of God, Nigeria current facts'. The Living Faith Church Worldwide, symbolised in Oyedepo, has a list of ceremonies described as 'The power channels' (Oyedepo 2006:51), namely The mystery of the Holy Communion, the mystery of the Anointing Oil, the mystery of the blood, the mysteries of feet-washing, prophetic verdict, prophetic mantle and the Bread of life. Most of these ceremonies, snubbed by foreign missionaries as non-Christian and unbiblical, are now celebrated in Pentecostal churches in the most African fashion and grandeur.

\section{Theology and liturgy in the Assemblies of God, Nigeria and other Pentecostals}

Weekly activities in almost all AGN churches are structured in this order:

- Monday: Women fellowship - this brings all the married women in the congregation together to discuss church related issues, share needs and afflictions at home or in the working place. During such meetings the roles of women at home and in the church are discussed and reaffirmed. Space is open for women with unsaved husbands or children to make their requests known to the group for prayer and counselling.

- Tuesday: Bible study - it is regarded as the pastor's day to teach the members from the Bible. In the Bible study the leader of the service begins with a worship song and prayer for the man of God to receive illumination to communicate God's word to his people. Prayer is made against all forces of darkness that might disturb the pastor from speaking the Word of God with passion and clarity.

- Wednesday: Prayer meeting - this is for all members to come and pray for personal as well as community needs. Prayer is made for Thursday's activity, and directed against territorial demons that work to prevent people from receiving Jesus Christ as their personal Lord and saviour.

- Thursday: Evangelism - this day all members are strongly counselled to participate.

- Friday: Preparatory class - this class is for Sunday school workers. The Pastor must teach the prep-class and sits on Sunday as the Headmaster of the Sunday school.

- Saturday: Choir practice - choir members come to practice; however, non-choir members are also obligated to join the Pastor and other members to do visitation to hospitals, prison, homes and other designated places where they pray and persuade people to come to their church.

- Sunday service: A Sunday service bulletin is not produced or available in most Assemblies of God churches. The leader of the service alone possesses the script of the programme. A sample copy of the order of the service for the Sunday service is outlined below:

\section{Order of the Sunday service}

A Sunday service comprises of the following eight components: prayer, choir - congregational praise, announcements, tithes and offering, choir sings before the preaching, the Word (homily), altar call, prayer for children and pregnant women and those in need, and benediction.

It is pertinent to critically discuss selected items of the above order of the Sunday service following seriatim:

- Prayer: The prayer leader could be an elder, male or female of the church. All prayer points are many a time proposed extempore, and usually focused against territorial spirits capable of attacking the 'man of God' (the pastor). Current 
happenings in the community that could generate fear are mentioned and all would be urged to open wide their mouths and pray. An example of such current happenings could be the unfortunate but sudden death of a person in an airplane crash, a car crash or a fall from a tall building. With such examples, all members must pray against the spirit of death in their families and individually reject such deaths by proclaiming 'it shall never be my portion in the name of Jesus'. Scriptures such as Psalm 118:17 are quoted and appropriated in this manner: 'I will not die but live'. Furthermore, Psalm 91:7 is personalised: 'A thousand may fall at my side, ten thousand at my right hand, but it will not come near me.' In like manner, all other prayer points are handled and summarised before inviting the choir to the altar to lead in songs of praise.

- Choir or praise worship group: It is usually at this point of the service that the unaccustomed visitor finds the Pentecostal praise and worship noisy, sweaty and chaotic as all instruments are competitively used indiscreetly. In almost every Pentecostal worship service one finds that 'music and dance traditions have attempted to supplant the music and dance of discotheques' (Kalu 2008:21). As stated above, African traditions have now displaced foreign mission paradigm in Pentecostal liturgy. 'A number of high-profile secular or "juju" musicians (who create new rhythms from indigenous musical culture) have become gospel singers, evangelists, and pastors' (Kalu 2008:121). Pentecostal churches are full of men and women who are competing among themselves in all spheres of life. For this reason, the revelation of God's design of all things in creation for his pleasure is relegated in Pentecostal liturgy. African traditional praise-songs normally directed to boost the ego of the African chief, are now appropriated by individuals in Pentecostal worship. A few examples of this are in order: ('I never knew he will honour me this way thrice). Honour me this way thank you Jesus'). At this, every congregant feels exulted as an honoured person in the worldly sense of wealth acquisition. Unfortunately, it is never from the perspective of the work of Christ on the cross by which people of all races, irrespective of class or creed have been made one in Jesus Christ. The second example is: ('Eeeeh, Eeeeh my God is good o (thrice). He gives me wife o, He gives me car o, He gives me house o; everything is double double, everything is double double'). All material things are here mentioned as having been twice supplied or provided for the gorging oneself. However, Paul the apostle reminds us that Christian singing should:

represent an example of godliness by which the whole community can encourage one another with the acts of God in the past, present, and future, employing the inspired psalms and hymns of Scripture as well as 'spiritual songs' composed by later believers, reflective of the greatness of God in Christ (VanGemeren 1988:472).

- Announcements: This aspect, in most cases, usually does not last for fifteen minutes, though people have complained that announcements are boring and timeconsuming.
- Tithes and offerings: African traditional concepts of spirits are that they take part in the activities of the living - nonAfricans call this belief animism. The fear of the unknown and the terror of the unseen are common among Africans. To assuage their fear of the unknown, African Christians rely on visions and prophecies. But many Pentecostal churches, and especially AGN have lost the power to release prophecies or see visions for individuals within the congregation. Traditional Africans believe that when worship takes the form of gifts to the spirits, troubles hidden in the unknown future will be kept away from the worshipper. The paradigm shift from visions and prophecies results in Pentecostal's great emphasis on giving. The theological deception is that the congregation is not taught how the individual could appropriate the Pentecost as found in the book of Acts.

- The Word (or homily): This is the most crucial part of every Pentecostal Sunday service. The service leader humbly introduces the pastor as the attraction of the day in the manner Nigerians bestow academic and ecclesiastical titles on whoever is considered important. Examples of sermon delivery from two Pentecostal churches serve well here: The preacher announced the text: 'Open with me to Luke chapter 10:25-37. I say it again, open with me to Luke 10:25-37.' Without paying attention to the context, the preacher isolated verse 30 and shouted, 'set your finger on verse 30 ', and read with me 'A man was going down from Jerusalem to Jericho'. The preacher kept shouting and pointing at the congregation of people, 'You will not go down, you will not go down, your children and family will not go down, your business and estate will not go down.' The people responded with the loudest Amen! This served as sermon introduction, body and conclusion of the message. The second example is from John 11:1-44. The preacher read the text and proclaimed that just as Lazarus was dead, 'there are many dead wombs in this church, there are many dead businesses, and dead families here; Lazarus was bound hand and foot with grave clothes, there are families and people that the Devil has bound with grave clothes, but I prophesy to you, come out of your graves, come out of your graves and be loosed, be loosed in the name of Jesus.'

The obvious weakness of the majority of Pentecostal preachers has been the lack of sound hermeneutical guidelines to move from text to exegesis and to exposition. This obvious weakness among Pentecostals to practice an advanced level of theology is a pervasive phenomenon which McCain (2011) aptly illustrated from a personal experience:

I have been teaching Pentecostal students for the past 23 years. I currently teach on an adjunct basis at both West Africa Theological Seminary, Lagos [WATS] and Evangel Theological Seminary, Jos [ETS], both of whom enrol primarily Pentecostal students. I have found them to be very eager students and often very good students but as a general rule, I have found them to have less general knowledge about theology and hermeneutics, in particularly, than their counterparts in the mainstream 
churches. Because of this limitation, there is a tendency within Pentecostal churches to preach textual sermons in which the preacher focuses on just one phrase of Scripture. (p. 16)

Because liturgy is hardly part of the course contents in AGN Bible institutes, it is difficult for the church to achieve uniformity in its Sunday or weekly services. In fact many other weekly programmes in all AGN churches are unpredictable in terms of uniformity. The great concern has been whether the average AGN clergy understands the centrifugal theological implications of the contents of the order of the Sunday service for the community. The dearth of the knowledge of the interconnectedness of liturgy, sociology, and psychology for understanding how communal and personal identity are both expressed and shaped by church rituals makes participation in AGN church Sunday services or weekly activities a drudgery exercise. What one observes in church services is that each item in the order of the Sunday program is interpretively conducted along individual needs without enunciating the principle of community life that goes beyond the circumstances of the individual in prayer and worship of God. One of the most outstanding Pentecostal ordinances, the Lord's Supper merits a detailed discussion.

\section{The Lord's Supper (Holy Communion)}

As found in the official documents of leading Pentecostal churches in Nigeria, the Lord's Supper (Holy Communion) has become an integral part of Pentecostal church life as one of their ordinances. The time for observing the Lord's Supper varies from one Pentecostal church to another. Some Pentecostal churches observe the Lord's Supper every Sunday evening. No official dates for observing the Lord's Supper are fixed for all AGN churches in Nigeria. Generally, other Pentecostal assemblies in Nigeria have vague rules about the frequency of observing and taking the Lord's Supper. Bishop Oyedepo's Living Faith Church always known as Winner's Chapel) teaches that the Holy Communion should be taken as often as possible (Oyedepo 2006:91-92). Below is an example or the order of service for Holy Communion as it is obtainable in most Pentecostal churches: Opening prayer, Praise and worship, Opening hymn, Scripture reading and the message (Homily), Prayer for sanctification of bread and wine, Breaking, serving and eating bread, Breaking, serving and drinking of wine, Personal time for prayer and reflection, Celebrating with praise and worship, Taking of love offering, Announcements, and Closing hymn, prayer and benediction.

Regarding the Lord's Supper that is a focal point of worship in the church, Paul the apostle wrote to the Corinthians:

\footnotetext{
${ }^{23}$ The Lord Jesus, on the night he was betrayed took bread, ${ }^{24}$ and when he had given thanks, he broke it and said, 'This is my body, which is for you; do this in remembrance of me.' ${ }^{25} \mathrm{In}$ the same way, after supper he took the cup, saying, 'This cup is the new covenant in my blood; do this, whenever you drink it, in remembrance of me.' ${ }^{26}$ For whenever you eat this bread and drink this cup, you proclaim the Lord's death until he comes. (1 Cor 11:23-26)
}

Beginning with the Roman Catholic doctrine of transubstantiation in which the elements of bread and wine are miraculously changed into the actual body and blood of Jesus through the Lutheran, Zwinglian, Calvinist views, there has been widespread disagreement among Christians about details of meaning and practice of what is eaten (symbolic bread or actual body); what is drunk (symbolic wine or actual blood) of Jesus Christ during the celebration of the Lord's Supper. The Passover feast Jesus had with his disciples shortly before He went to the cross, has been described by various names (Culver 2005:992): 'the meal of love feast' (Jude 12), the' communion' (1 Cor 10:16 KJV), 'breaking of bread' (Acts 2:42; 20:7), 'Eucharist or thanksgiving' (Lk 20:19). Though refrained from use because of its 'Roman Catholic Mass and of sacramentalism overtones, the term "Eucharist" (thanksgiving), fits in with the bread and cup as distinct from the customary meal or love feast' (Culver 2005:992).

By way of situating this section in context, it must be stated that very few Africans are ignorant of traditional African customs of eating and drinking together as acts of public and private fellowship linked with kinship, clanship and with the sacred. Having common meals together strengthens the bonds of friendship and represents their union with the family, clan or tribal deity. The meals, especially when connected with the deity, are perceived to be divinely embodied and nothing directly unites the people with themselves and with their deity more than eating and drinking together. The traditional African soundly believes that through the meal the individual as a person or the family, clan or tribe as a whole enters into fellowship with the deity. Among Native Americans, material things could be 'focal points for sacred power; specific places in the natural environment were understood to be imbued with sacred significance' (Chidester 1991). The same religious view is common in Africa where invitation to eat in a particular sacred place or with a particular person is perceived as an honoured communion with a higher power. A corollary view is the claim that Paul's interpretation of the Lord's Supper could be traced to heathen, Hellenist memorial feasts familiar to the Gentile believers. It does not constitute any surprise element therefore, that many African Pentecostals could interpret the Lord's Supper as a supernatural meal. Bishop Oyedepo (2002:16; repeated also in 2006) the Charismatic leader and founder of Winner's Chapel has interpreted John 6:55 and Mark 14:22-24 in this manner:

When God opened my eyes to the flesh and blood of Jesus, I was so taken with it that I took it virtually every day. It answered to me in detail. All weakness and sickness in me died and life became increasingly more buoyant. This meal is designed for strength, health and longevity. If you take it with the correct spiritual perspective, expect to be strong, healthy and fulfil the number of your days. (pp. 62-63)

Oyedepo's manner and way of interpretation of the Lord's Supper aligns with ancient religious ceremonies of a meal in a sacred place where the god himself as an unseen guest 
(Barclay 1962:261) enters in all his divine life and strength with the food and meat of the sacrifice. Oyedepo interprets the Lord's Supper as a diet with ultimate nutritional value like the manna. His main text for celebrating the Lord's Supper is centred on John 6, which is not about the Lord's Supper, but rather the Lord's Supper is about what is mainly described in John 6 . This is how the discourse is worded in John 6:36, 48, 50-56:

I am the bread of life. Your fathers ate the manna in the desert, yet they died. But here is the bread that comes down from heaven, which a man may eat and not die. I am the living bread that came down from heaven. If anyone eats of this bread, he will live for ever. This bread is my flesh, which I will give for the life of the world. I tell you the truth, unless you can eat the flesh of the Son of Man and drink his blood, you have no life in you. Whoever eats my flesh and drinks my blood has eternal life, and I will raise him up at the last day. For my flesh is real food and my blood is real drink. Whoever eats my flesh and drinks my blood remains in me, and I in him.

The story of bread from heaven was deeply imprinted on the Jewish memory; it immediately turns the thoughts of a Jew to the manna which God gave them on their way to Canaan. Of this manna, Josephus (1981) says:

So divine and wonderful a food was this! It also supplied the want of other sorts of food to those that fed on it; and even now, in all that place, this manna comes down in rain, according to what Moses then obtained of God, to send it to the people for their sustenance. So the Hebrews were very joyful at what was sent them from heaven. Now they made use of this food for forty years, or as long as they were in the wilderness. (p. 67)

To the Hebrew there was something mysteriously divine about the manna, it is part of their messianic belief that, when the Messiah came, He would once again feed his people with the heavenly manna (Barclay 1962:259). And for Jesus to claim that He was the bread from heaven was in itself a claim to be divine, the concept which the Jews seemed clearly to have understood and therefore began to grumble (Jn 6:41). But could the disciples have taken 'this is my body'; 'this is my blood' literally when Jesus is physically present with them at the meal? The understanding of Oyedepo, along with other African Pentecostals, is that the quality of the manna is superseded by the flesh and blood of Jesus. The manna varied in itself according to the need and wish and condition of the eater. Whatever the eater needs, the manna provides just that. And the claim of Jesus is that whatever is considered a human need, he can satisfy it.

\section{A brief theological explanation of the significance of the Lord's Supper}

The New Testament texts understood the Lord's Supper, and the sacrifice Christ made on the cross of Calvary as a means of bringing to memory Jesus' death for his creation, of revelling in communion with him, and drawing from him life that defeats death, while at the same time anticipating his physical return to earth in glory (Davies 1992:254). Quite a large number of African Pentecostals have accepted in theory the finished work of Christ on Calvary, but have not made the involved sophisticated philosophical adjustment by transcending their sensible and tangible experience or world of senses. The grounding of the celebration of the Lord's Supper on cultural and linguistic backgrounds is the inability to perceive that things independent and external to the mind do really exist. African Pentecostal's praxis has not transcended entrenched traditional African context and worldview. This is the reason why the reality of the Lord's Supper is interpreted mainly from the viewpoint of human experience without capturing God's character, nature and attributes. Apostle Paul gives clear guidance in 1 Corinthians 11 regarding the Lord's Supper: proclaiming and sharing. In essence, the church's celebration of the Lord's Supper is a visible proclaiming of the gospel, pointing in particular to Jesus' sacrificial death as the eternal means of the salvation of those who believe. When the church meets in the name of Jesus and celebrates the Lord's Supper, a corporate worship is thereby encouraged and fellowship with Jesus renewed.

The Lord's Supper is rich in significance as believers eat together from one loaf they thereby declare their fellowship with fellow believers. This is not to be with Pentecostal believers who come to partake of the Lord's Supper in order to appropriate individual healing or to achieve personal success. Thus, the significance of Christian fellowship at the Lord's Supper is lost because of the clerics' superstitious interpretation, according to Oyedepo (2002), that upon eating (the flesh) and drinking (the blood) of Jesus:

Every zero sperm count, dead womb, dead ovaries, whatever is called dead will be quickened back to life by the power in the blood contained in this miracle meal. The power in the blood is what cured a brother's impotence - it quickened that which was dead. (p. 40)

Oyedepo's statement above both reflects and enacts the Corinthian errant abuses, which arose because the Lord's Supper was conceived as granting the individual participant the food of immortality. The Lord's Supper does not merely recall the Last Supper that Christ ate with his disciples, but primarily constantly serves as reminder and experience of the efficacy of the death of Christ for his creation (Fee 1987:558). The meaning of the Lord's Supper is to unite those sharing in it together as members of the body of Christ whose concern is simply not personal or introspective. This is the vital point that African Pentecostal preachers have clearly missed, hence the soteriological implication of the Lord's Supper has been laid waste through commercialisation of the liturgy. Pentecostals in Nigeria in their writings and preaching have deemphasised the fact that salvation through Christ's death has created a new community - an alternative community - of people who bear his name (Fee 1987:558). Bonhoeffer (1954) refers to this community as 'the physical presence of other Christians' and says that:

Man [sic] humankind was created a body, the Son of God appeared on earth in the body, he [sic] was raised in the body, in the sacrament the believer receives the Lord Christ in the body, and the resurrection of the dead will bring about the perfect fellowship of God's spiritual-physical creatures. Christianity 
means community through Jesus Christ and in Jesus Christ. No Christian community is more or less than this. (pp. 19-21)

The theological pitfall that Pentecostals in Nigeria must avoid is the conception of the Holy Communion as a 'magical meal' with powers of physical healing. Bishop Oyedepo's (2006:61-93) interpretation of the Holy Communion as a 'supernatural meal, a balanced diet with medicinal value' runs the risk of conveying the same interpretation that the 'Holy Communion should be a real sacrament, conveying forgiveness of sins and saving grace' (Bloch-Hoell 1964:170).

What is immediately obvious in Nigeria is that Pentecostal Christians and clergy have developed an abashed view of the cross. God is conceived as not autonomous and therefore can be manipulated by cultic rituals, offerings and first fruits. What African gods demand is largely ritual in nature, and since they had needs that were dependent on humans to provide, the gods could be manipulated. There is no other form of prosperity theology that demonstrates the shallowness of 'African Pentecostal theology' in Nigeria as the tying of business management strategies to almost all aspects of Pentecostal liturgy. ${ }^{4}$ The erroneous emphasis on 'faith as the route to prosperity, based on acting on the word, speaking into reality what does not exist, and dreaming and envisioning the desired goals' (Kalu 2008:255) has been repacked to assume the nature of African method of ritual performance.

There are innumerable rituals and ceremonies in Africa that have since found their way back to Pentecostal churches in Nigeria where God has been made a means to an end instead of the end itself. Most African religious rituals which are performed to achieve some sort of psychological confidence (Mbiti 1991:132) to promote the power of imagination by utilising the right word in the form of incantation (Kalu 2008:256-257) have since become part of Pentecostal liturgy. In their futile endeavour at 'popular' approach to understanding and interpretation of the Bible, African Pentecostals are inordinately behaving as if the Bible had been written in their own mother-tongue, culture and time (Tienou 1990:12). From the time of European missionaries till today, generations of African Pentecostals have failed, for two reasons, to remain theologically distinct, namely because the African Pentecostals' dislike and mistrust of theology, and secondly, the acute dearth of higher theological training for Pentecostals in Nigeria. Who is to blame? The Pentecostal church leaders and their evangelists whose failure has hastened the decline of Christian living and pastoral influence are to blame for this lapse. ${ }^{5}$

\section{Conclusion}

Pentecostal liturgy has gone through paradigm shifts from the Early Church's affiliation with synagogue liturgy. In

\footnotetext{
4. They teach that one must sow in order to reap, sow tithes, and offerings, donate the whole salary of the first month of the year as first fruit, and so on.

5.Judges 17-21 and 1 Samuel 2-4 are a few of the Scriptures that support the apportioning of blame on Pentecostals.
}

Africa, Pentecostal liturgy resonates with the Early Church cum synagogue and Wesleyan Holiness movement liturgies. Presently, Pentecostals in Africa and Nigeria are borrowing much from African traditions and culture. What is apparent is that Pentecostal liturgical discourse considers biblical texts, African traditions and performance as inseparable entities. Employing the paradigm shift discourse, this article explored Pentecostals' liturgical performances, showing how the textually enshrined promise of God is adversely regurgitated to promote the primacy of individual existence over and above community performance of the rite as a kingdom principle. The act of worship invites participants to appropriate this promise for themselves at communal level. The article identified a dialectical manifestation embedded in Pentecostal liturgy. Firstly is the modelling of African traditions in the performance of rites while they are still uncritically engaging the biblical text. The second manifestation is Pentecostal's promotion of Christian individuality at the expense of the African tradition and religion that functions more on a communal than an individual basis (Mbiti 1991:15). In short, the article shows that Pentecostal's practice of worship encourages the individual to appropriate the promise of the kingdom of God at the expense of the community of the King, whose work in building character and guiding our lives is often done through other Christians in the community.

\section{Acknowledgements Competing interests}

The author declares that he has no financial or personal relationships which may have inappropriately influenced him in writing this article.

\section{References}

Assemblies of God, 1994, Current facts, Donze Press, Enugu.

Barclay, W., 1962, Jesus as they saw him, SCM, London.

Bloch-Hoell, N., 1964, The Pentecostal movement: Its origin, development, and distinctive character, Universitetsforlaget, Oslo.

Boer, H.R., 1976, A short history of the Early Church, Daystar Press, Ibadan.

Bonhoeffer, D., 1954, Life together, transl. John W. Doberstein, Harper \& Row, New York, NY.

Bright, J., 1959, A history of Israel, rev. edn., SCM, London.

Bruce, F.F., 1969, New Testament history, DoubleDay, New York, NY.

Chadwick, H., 1993, The penguin history of the church, 1: The early church, Penguin Books, London.

Chidester, D., 1991, 'Primal religions' in J.W. de Gruchy (ed.), A Southern African guide to world religions, pp. 13-32, David Phillip, Claremont.

Cole, E., 2007, 'Nigerian Pentecostalism thriving on miracles, prosperity promises', in Christian Post, viewed 27 March 2015, from http://www.christianpost.com/news/ nigerian-pentecostalism-thriving-on-miracles-prosperity-promises

Culver, R.D., 2005, Systematic theology: Biblical and historical, Christian Focus Publication, Ross-shire

Davies, R., 1992, 'Proclaiming his death' in D. English (ed.), An introduction to the Christian faith, pp. 254-257, Lynx Communications, Oxford.

De St. Jorre, J., 1972, The Nigerian civil war, Houghton Mifflin, Boston, MA.

Dyrness, W.A., 1989, How Americans hear the gospel, Eerdmans, Grand Rapids, MI.

Fee, G.D., 1987, The first epistle to the Corinthians, Eerdmans, Grand Rapids, MI.

Josephus, F., 1981, The complete works of Josephus, transl. W. Whiston, Kregel Publications, Grand Rapids, MI.

Kalu, O., 2008, African Pentecostalism: An introduction, Oxford University Press, New York, NY. http://dx.doi.org/10.1093/acprof:0so/9780195340006.001.0001 
Kuhn, T.S., 1962, The structure of scientific revolutions, University of Chicago Press, Chicago, IL.

Latourette, K.S., 1975, A history of Christianity: Beginnings to 1500, vol. 1, Prince Press, Peabody, MA.

Lonergan, B., 1973, Method in theology, Herder \& Herder, New York NY.

Martin, R.P., 1964, Worship in the Early Church, Eerdmans, Grand Rapids, MI.

Mbiti, J.S., 1991, Introduction to African religion, 2nd edn., East African Educational Publishers, Nairobi.

McCain, D., 2011, “Us and them": Pentecostal and other challenges and learning from each other', paper presented at the Theological Education in Africa conference, Theological College of Northern Nigeria (TCNN), Jos.

McGee, G.B., 1986, This gospel shall be preached: A history and theology of Assemblies of God foreign mission to 1959, Gospel Publishing House, Springfield.
Oyedepo, D., 2002, The miracle meal, Dominion Publishing House, Canaan Land. Oyedepo, D., 2006, Signs and wonders today, Dominion Publishing House, Canaan Land.

Sanneh, L., 1983, West African Christianity: The religious impact, Orbis Books, New York, NY.

Spittler, R.P., 1983, 'Scripture and the theological enterprise: View from a big canoe' in J. Robert (ed.), The use of the Bible in theology: Evangelical options, pp. 54-77, John Knox Press, Atlanta, GA.

Tienou, T., 1990, The theological task of the church in Africa, 2nd edn., African Christian Press, Achimota.

VanGemeren, W., 1988, The progress of redemption, Baker Books, Grand Rapid, MI.

Work, T., 2006, 'Pentecostal and charismatic worship', in G. Wainwright et al., The Oxford History of Christian Worship, pp. 574-585, Oxford, New York, NY. 